\title{
Digitalization of Enterprise Development Security Management Based on Cognitive Approach
}

\author{
Viktoria Prokhorova, Roman Korzh, Svitlana Mushnykova, Olena Bozhanova
}

\begin{abstract}
The introduction of digitalization as an innovation in economic processes is necessitated by the need to enter the world community, in order to further expand the markets for products, goods or services, to ensure the development of domestic national markets, increase the level of competitiveness, etc. The digitalization of enterprise security management is one of the priority places in the enterprise management system. The key objective of digitalisation is to meet public needs in the most efficient way through the introduction of digital technologies and platforms. On the other hand, existing methods of analyzing the impact of factors on the level of security of enterprise development, need generalization and specification. It is the use of cognitive methods of analysis that makes it possible to take into account the factors of external and internal influence for poorly structured systems such as enterprises.
\end{abstract}

In the digital economy, the key place of any enterprise's resource is occupied by information resources expressed by digital data: numerical, textual, etc. The use of digital data as a resource in managing enterprise development security can significantly improve the effectiveness of management decision making by defining more scenarios while reducing the time to analyze relevant data.

Adhering to the basic principles in the digitalization of the security management of the development of the enterprise, it is possible to completely or partially (depending on the conditions of functioning of the existing) to avoid the negative consequences of the influence of factors of external action. To date, a large number of principles for digitizing the economy as a whole and the real sector separately have been formulated and generalized. However, considering the digitalization of development security management as an innovative process in the enterprise management system, the general scientific and specific principles of digitalization are highlighted.

With digitalization, the use of a cognitive approach to managing the enterprise's development security becomes more effective through the use of digital platforms: BlockChain, Digital Marketing, CRM \& BPM, Digital Insurance - by which it is possible to increase the number of scenarios to form a generalized the enterprise management system.

Revised Version Manuscript Received on October 15, 2019.

Victoria Prokhorova, the Department of Economics and Activities of Economic Entities, Ukrainian Engineering and Pedagogical Academy, Kharkiv, Ukraine. Email: vkprohkorova@gmail.com

Roman Korzh, the Departmen of Electronics and Information Technology, Lviv Polytechnic National University, Lviv, Ukraine. Email: college@lpnu.ua

Svitlana Mushnykova, the Department of Finance, National Metallurgical Academy of Ukraine, Dnepr, Ukraine, Email: svetamush@gmail.com

Olena Bozhanova, the Department of Finance, National Metallurgical Academy of Ukraine, Dnepr, Ukraine, Email: bozhanovaelena68@gmail.com model of the situation and choose the best management solution in

Keywords: digitalization, development security, enterprise, economic processes, digital technologies and platforms, cognitive approach, factors of influence.

\section{INTRODUCTION}

Recently, the necessity of digitization of all levels of the national economy, from meso-, macro-levels to micro-levels has been determined. This is due both to the need to enter the world community, to further expand the markets for products, goods or services, and to ensure the development of domestic national markets, improve competitiveness, etc. However, there are some obstacles to implementing effective socio-economic development today. In this case, there is an unstable economic situation in country where there is a real sector of the economy, and, above all, it is caused by the influence of external factors such as: the general economic situation in the country, the volatility of political expectations, the imperfection of regulatory and regulatory activity, antitrust regulation, etc. This, first of all, affects the performance of each individual enterprise and the direction of the vectors of their economic development, the formation of internal factors affecting the level of security of development. Therefore, the digitalization of enterprise security management is one of the priority places in its management system. The key objective of digitalisation is to meet public needs in the most efficient way through the introduction of digital technologies and platforms. On the other hand, existing methods of analyzing the impact of factors on the level of security of enterprise development require generalization and concretization in the appropriate conditions of enterprise functioning. It is the use of cognitive methods of analysis that makes it possible to take into account the factors of external and internal influence for poorly structured systems such as enterprises.

\section{LITERATURE REVIEW}

The issue of digitalisation of the economy in recent years has received a great deal of attention at all levels of the national economy from the State authorities [2] to Ukrainian scientists outraged by such issues as: O.Arefyeva, V. Prokhorjva [1], N. Kraus, O. Goloborodko [6], V. Lyashenko [9], Gavkalova N., Lola Y. [3]. 
Particular attention is given to the use of a cognitive approach to business process management, the construction of cognitive models, which is reflected in the works of such scientists as: M. Makarov [10], Lanlan Cao, Jyoti Navare, Zhongqi Jin [7], Kevin McCormack, Nancy Rauseo [5].

However, insufficient attention has been paid to the issue that combines digitization processes with enterprise development security management.

\section{THE AIM OF THE PAPER}

The purpose of the paper is to substantiate the feasibility of introducing digitalization processes in the management of enterprise development based on a cognitive approach.

\section{RESULTS AND DISCUSSION}

As outlined in the Economic Strategy of Ukraine 2030, digitization of the economy should become the main tool in achieving the strategic goal of Ukraine - to increase GDP by 8 times, up to $\$ 1$ trillion in 2030, and ensuring the well-being, comfort and quality of life of Ukrainians at a level higher than the average in Europe [2], with a $65 \%$ share of the digital economy in Ukraine's GDP under the conditions of the accelerated development scenario. However, it is impossible to achieve the results of national priorities without the participation of the real sector of the economy, whose share in GDP is about $60 \%$. That is why, first of all, digitalization must be developed at the level of economic entities. On the other hand, the main thing the direction of any development, including digitalization, of the entity is to ensure the management of its security, that is, the management of development security as an economic process in different operating conditions.
1. In the digital economy, the key place of any enterprise's resource base is occupied by information resources expressed by digital data: numerical, textual, etc. The use of digital data as a resource in managing enterprise development security can significantly improve the effectiveness of management decision making by defining more scenarios while reducing the time to analyze relevant data. However, there is a close correlation between the amount, quality of information supplied to the enterprise through the use of existing information and communication technologies and the competence of the personnel who select and process it in the conditions of digitalization of the security management of the enterprise development. Over the last decades, the Internet has been increasingly important in obtaining information from every level of interest of every enterprise: from regulatory regulation of activity, state of internal and external markets to financial and economic status of suppliers and consumers of products, goods, services, etc. Along with the quality information needed to carry out an effective activity, there is a considerable amount of poor quality information, which in turn, has a negative impact on the development of the enterprise. Therefore, we believe that information today is a primary resource that affects the performance of any enterprise, its development and should provide a certain level of security regardless of the time of its collection and processing, whether strategic interval, tactical or operational. The role and place of civilization in managing the security of enterprise development can be represented in the form of a scheme (Fig.1). 


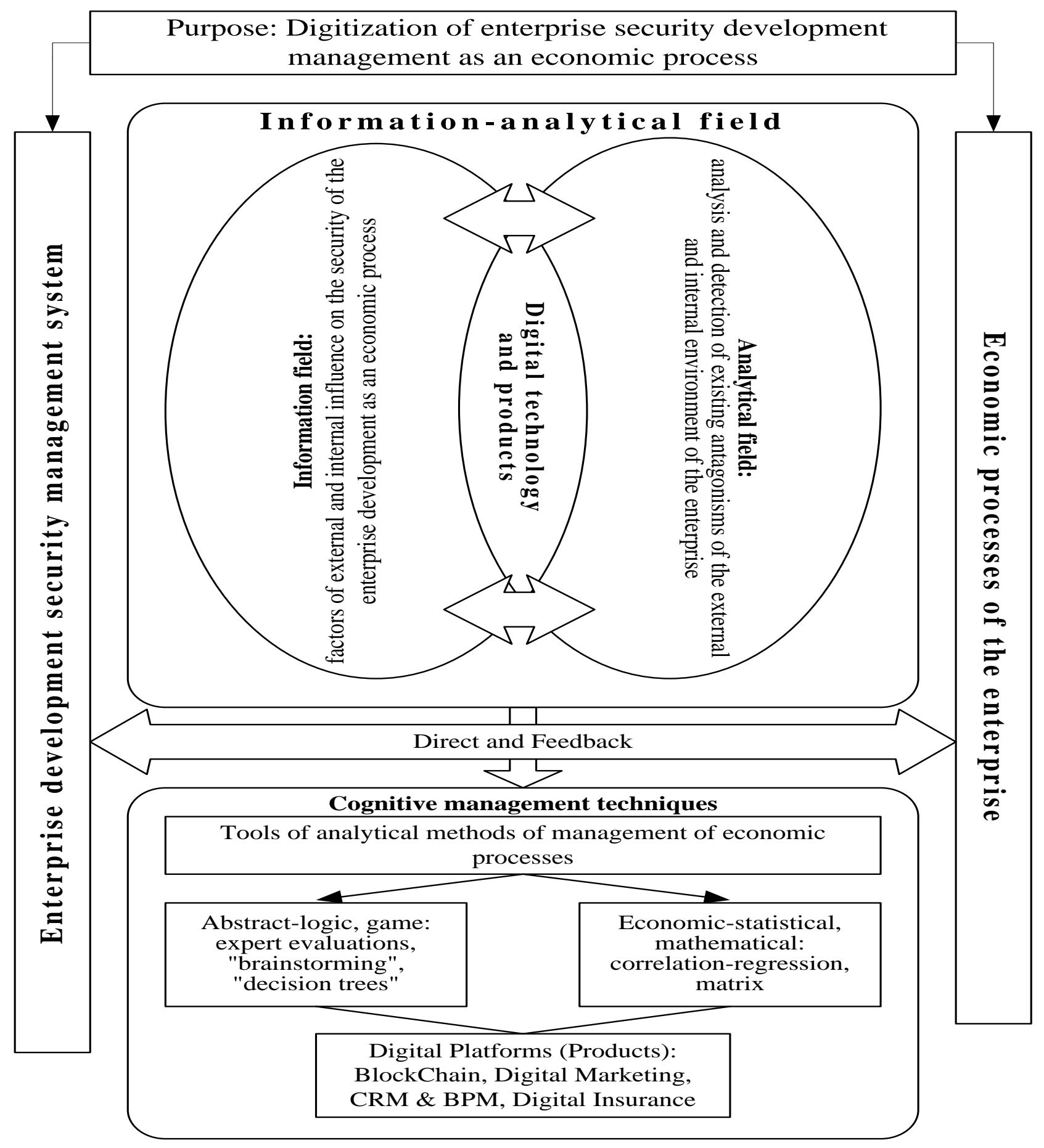

Figure 1. The role and place of digitalization in the enterprise security management system

Information as a resource for its further effective use (analysis, management decision making) in the enterprise security management system is collected and processed in the information-analytical field for the detection of existing antagonisms of the external and internal environment of the enterprise with direct and feedback. The use of digital technology and products enables us to address issues automated collection and analysis of existing information.The digitalisation of development security management has both positive and negative features.

The positive features of digitalization management security development of the enterprise include

- accelerating the collection and processing of information;

- structural restructuring of economic processes;

- reduction of administrative costs;
- raising the level of productivity of decision-makers;

- reduction of risks of business activity;

- partial leveling of incompleteness of information;

- improving the effectiveness of managerial decision making;

- strengthening the competitive position of the enterprise as a whole;

- access to new markets, expansion of export opportunities;

- increasing investment attractiveness. 
Along with the positive properties of digitalization, there is a likelihood of an onset and negative consequences, such as:

- receiving of low-quality false information;

- low level of competence of the personnel who conduct the collection and processing of information;

- reduction or loss of the level of security of information of internal origin and use;

- the possibility of fraudulent intervention in the enterprise management system.

Adhering to the basic principles in the digitalization of the management of the security of the enterprise development it is possible to completely or partially (depending on the existing conditions of operation) negative consequences. To date, a large number of principles for digitizing the economy as a whole and the real sector separately have been formulated and generalized [6]. But, considering the digitalization of development security management as an innovative process in the enterprise management system, it is necessary to allocate general scientific and clarify specific principles of digitalization (Fig. 2).

The general scientific principles of digitalization of the security of enterprise development are closely related to each other. Surely, the purpose of digitalization should be aimed at creating revolutionary advantages of security of enterprise development, and only under the conditions of truth and reliability of the information space.

Along with the principle of digital accessibility, according to which every subject has equal opportunities to access services, information and knowledge provided on the basis of digital technologies, the principle of security and trust should be respected, through confidence building, including information security, cybersecurity, protection of confidentiality of information, privacy and user rights of digital technologies and products.

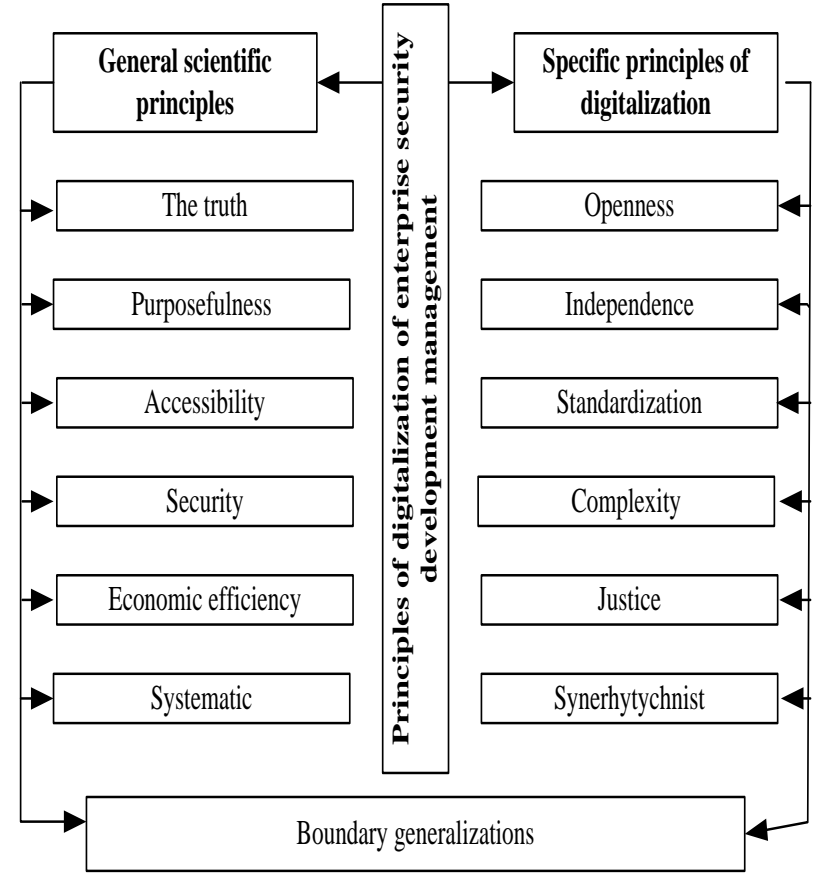

Figure 2. Principles of digitalization of enterprise security development management.

The principle of cost-effectiveness is closely linked to the principle of systematic nature, because the best use of the resources needed to digitize the security of enterprise development is possible only if a systematic approach to optimize their use.

The specific principles of digitalization are closely linked to the information flows of the enterprise. In accordance with the principle of openness, the digitalization of enterprise security development management should focus on expanding international and regional cooperation in order to expand markets, obtain external financing for innovative projects, including the spread of digitalization.

The principle of independence of digitalisation should promote the development of the information environment, the media, the "creative" environment and the "creative" market, etc. In the creation of an open information space, the creation, distribution and preservation of the content, ie content in different languages and formats with due recognition of the rights of the authors, plays a decisive role. The creation of content, primarily Ukrainian, in accordance with national or regional needs, should contribute to social, cultural and economic development, to strengthening the information society. The freedom to seek, receive, impart and use information to create, accumulate and disseminate knowledge is a key factor in the security of the enterprise's information space.

The principle of standardization calls for the development and use of open, functionally compatible, non-discriminatory standards with basic elements of digital and business-oriented and open market-oriented development and dissemination.

In line with the principle of inclusiveness, there should be no obstacle on the part of the State administration and the political party on the digitalisation of security management enterprise development, and should play a leading role in developing, promoting, implementing national "digital" strategies.

The principle of fairness is aimed at establishing rules that must be followed by all members of the public and business entities. Synergies are closely linked to the principle of systematicity, however, the effect of each element of the digitalization of the security management of the development of the enterprise should increase the overall effect of the digitalization as a whole.

The overarching principle, which can be attributed to both general scientific and specific, is the principle of limit generalizations, according to which, in any situation of analysis and synthesis naturally based on self-organization or through intellectual actions formed a very generalized model of the situation, image, phenomena reality, that is, the core of cognitive and metacognitive technologies.

The use of a cognitive approach in managing economic processes has become increasingly popular lately. An approach that combines abstract-logical, game-based analysis with economic-statistical and mathematical methods allows us to determine the relationship between the influence of external and internal factors of action on the security of enterprise development. With digitalization, the use of a cognitive approach to managing enterprise development security becomes more effective through the use of digital 
platforms: BlockChain, Digital Marketing, CRM \& BPM, Digital Insurance - by which it is possible to increase the number of scenarios to form a generalized model of the situation and choose the best management solution in enterprise management system.

The cognitive approach, combined with the digitalisation of enterprise security development management, is focused on the activation of intellectual processes in presenting a problematic situation in the form of a formalized model. This is possible when using a cognitive map, which is a set of interrelated underlying factors and objects of the situation in the form of an oriented sign graph, in which its vertices are signs of the situation, and the arcs between them represent are cause and effect relationships, among which are the positive and the negative. With a positive connection, increasing the value of the factor-cause leads to an increase in the factor-consequence, with a negative - to its decrease [10].

At the same time, the choice of basic factors and objects is made using the algorithm of four-element strategic analysis of the environment - PEST-analysis (Policy - policy, Economy - economy, Society - society, Technology - technology and science). The situational analysis of the problem area is carried out by means of SWOT analysis, which allows to identify actual problems, bottlenecks, chances and threats for the object taking into account environmental factors. The cognitive graph is a simplified subjective model of the functional organization of the system under study and a material for further analysis and transformation. The purpose of building a cognitive model is to generate and test hypotheses about the functional structure of the observed situation to obtain a functional structure that can explain the development of this situation by predicting and interpreting qualitative forecasts of the situation (solving the direct problem "what if ..."), obtaining situation management tips and tricks (solving the "what it takes to..." solution). Then, based on multicriteria selection, a set of favorable scenarios, ranked by rank, is determined $[5,10]$.

The choice of basic factors and objects, their cause and effect relationships (positive or negative) for the digitalization of the security management of the enterprise development was reflected in the construction of the initial cognitive graph (Fig.3).

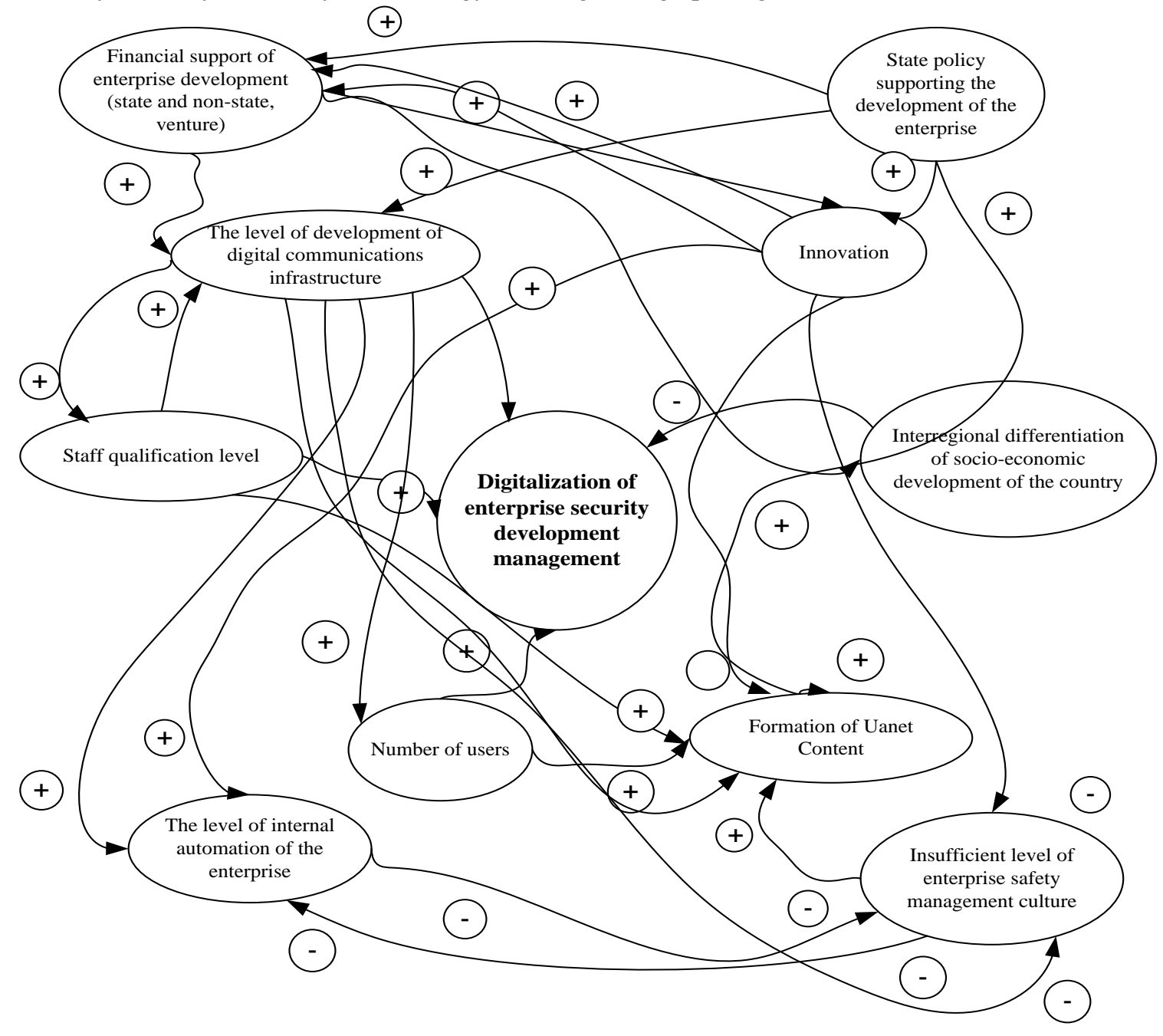

Fig. 3. Initial cognitive graph of digitalization of enterprise security development management 
An apparatus of sign and weighted oriented graphs is effectively used to describe cognitive models. The weights of the arcs of the cognitive model are determined either by statistical information processing or expertly. Changes in the values of factors are introduced step by step to determine the response of the system, after which, through multicriteria selection, many favorable scenarios to be ranked are determined. Cognitive analysis and modeling allow you to investigate the problem, take into account changes in the environment, determine the response of the system. For cognitive models, there is a requirement for their stability with respect to single impulse effects.

In modeling, such properties of processes and phenomena are ensured by the presence of positive, stimulating growth, and negative, feedbacks, as well as adjusting the parameters of these relations, which guarantee the fulfillment of these conditions.

\section{CONCLUSION}

The study substantiates the place and role of digitalization of the security management of the enterprise development, defines the basic general scientific and specific principles of digitalization. The expediency of using a cognitive approach in the management of economic processes, which combines abstract-logical, game-based methods of analysis with economic-statistical and mathematical methods, makes it possible to determine the interrelation of the influence of external and internal factors of action on the security of enterprise development.

\section{REFERENCES}

1. Arefyeva O., Prokhorova V., Chebanova N., Khaustova V., Mushnikova S. (2018). "Opening theory as an innovative model of the development strategy of industrial companies". International Journal of Engineering \& Technology, (7 (4.3)), p.387-392.

2. Cabinet of Ministers of Ukraine (2018), "About the conceptualization of the development of the digital economy for Ukraine and Ukraine for 2018-2020 and the hardening of the plan for entry into the project", available at: http://zakon.rada.gov.ua/laws/show/67-2018-\%D1\%80 (Accessed 05 Nov 2018)

3. Gavkalova N., Lola Y.,.Prokopovych S, Mykhailovych D. (2019), "Influence of the Country's Information Level on its Economic Development". Proceeding of the $20197^{\text {th }}$ International Conference on Modeling, Development and Strategic Management System (MDSMES 2019). AEBMR. Vol.99. Available: https://www.atlantis-press.com/ proceedings/mdsmes-19/articles?q=lola

4. Karaev R.A., Mikailova R.N., Safarli I.I., Sady`khova N.Yu., Imamverdieva Kh.F. Kognitivny`e instrumenty dlya dinamicheskogo analiza biznes-strategij predpriyatij ["Cognitive tools for dynamic analysis of enterprise business strategies"] Biznes-informatika, No. 1 (43), 2018. pp. 7-16. DOI: 10.17323/1998-0663.2018.1.7.16.

5. Kevin McCormack, Nancy Rauseo. Building an enterprise process view using cognitive mapping. Business Process Management Journal Vol. 11 No. 1, 2005 pp. 63-74 DOI 10.1108/14637150510578737

Available:www.emeraldinsight.com/1463-7154.htm

6. Kraus N.M., Holoborodko O.P., Kraus K.M. "Tsyfrova ekonomika: trendy ta perspektyvy avanhardnoho kharakteru rozvytku" ["Digital economy: trends and prospects of advanced development,"] Efficient economy,
No. 1, 2018. [Online]. Available: http://www.economy.nayka.com.ua /pdf/1_- 2018/8.pdf. [Accessed October 10, 2019]. (in Ukrainian)

7. Lanlan Cao, Jyoti Navare, Zhongqi Jin. Business model innovation: How the international retailers rebuild their core business logic in a new host country. International Business Review. Vol. 27 (2018), p.543-562.

8. Liashenko O.M. (2015). "Kontseptualizatsiia upravlinnia ekonomichnoiu bezpekoiu pidpryiemstva: monografiia". Kyiv: NISD.

9. Liashenko V.I, Vyshnevskyi O.S. (2018), "Tsyfrova modernizatsiia ekonomiky Ukrainy yak mozhlyvist proryvnoho rozvytku" [Digital modernisation of Ukraine's economy as an opportunity for breakthrough development]. Kyiv: NAS of Ukraine, The Economy of Industry Institute, (in Ukrainian)

10. Makarova M. V. Intellektual noe modelirovanie E-gotovnosti informaczionnoj e’konomiki ["Intelligent modeling of E-readiness of information economy"] Upravlyayushie sistemy' $i$ mashiny, No. 4, 2016, pp. 52-61. Available: http://nbuv.gov.ua/UJRN/USM_2016_4_7.

\section{AUTHORS PROFILE}

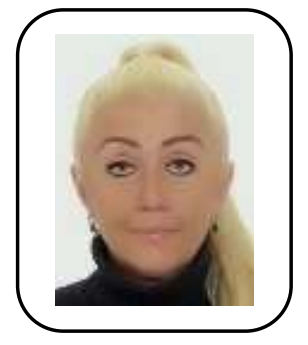

Victoria Prokhorova - Doctor of Economics, Professor, Head of the Department of Economics and Activities of Economic Entities, Ukrainian Engineering and Pedagogical Academy, Kharkiv, Ukraine. Author of more than 300 scientific papers. Scientific interests: investment-innovative activity of enterprises, renovation methods of development, management of financial rehabilitation. Teaches subjects: - crisis management; financial management; basics of the scientific research; business Economics.

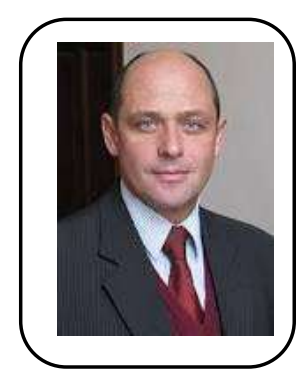

ORCID

iD: http://orcid.org/0000-0003-2552-2131

Roman Korzh - Vice-Rector on Scientific and Pedagogical work, Doctor of Engineering, Associate Professor of the Department of Electronics and Information Technology, Lviv Polytechnic National University. Author of more than 80 scientific papers. Scientific interests are concentrated in the field of mathematical modeling of radio-electronic systems and information

activities.

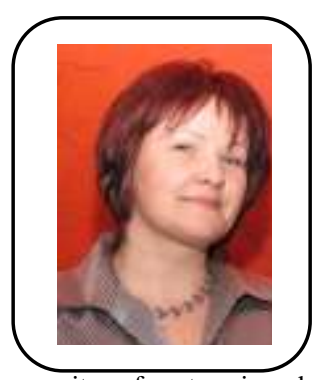

ORCID

iD:

https://orcid.org/0000-0001-8452-0203

Svitlana Mushnykova - Candidate of Economics, associate professor of the Department of Finance, National Metallurgical Academy of Ukraine, (Dnepr, Ukraine).

The author has more than 70 scientific and methodological works. The main area of scientific interest is management innovation, security of enterprise development, banking services and operations, management of financial activity of enterprises.

Teaches subjects - finance, banking system, financial controlling.

ORCID ID: https://orcid.org/0000-0002-3860-522X. 


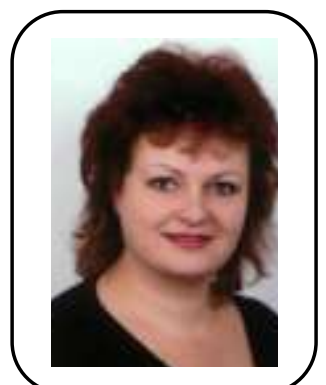

Olena Bozhanova - Candidate of Economics, associate professor of the Department of Finance, National Metallurgical Academy of Ukraine, (Dnepr, Ukraine).

Author of more than 60 scientific and methodological works. The main area of scientific interests is the investment and innovation activity of enterprises, economic potential of enterprises, financial security of enterprise development.

O. Bozhanova is the developer and teacher of the disciplines: "Innovation Management", "Financial Management at the Bank", "Finance of Foreign Corporations", Central Bank and Monetary Policy ".

ORCID ID: https://orcid.org/0000-0003-2927-7356. 